\title{
Influence of Adalimumab on the Expression Profile of Genes Associated with the Histaminergic System in the Skin Fibroblasts In Vitro
}

\author{
Dominika Wcisło-Dziadecka $\left(\mathbb{D},{ }^{1}\right.$ Beniamin Grabarek, ${ }^{2}$ Nikola Zmarzły, ${ }^{2}$ \\ Aleksandra Skubis, ${ }^{2}$ Bartosz Sikora $\mathbb{D},{ }^{2}$ Celina Kruszniewska-Rajs, ${ }^{2}$ Joanna Gola, ${ }^{2}$ \\ Urszula Mazurek (D), ${ }^{2}$ and Eugeniusz Kucharz ${ }^{3}$ \\ ${ }^{1}$ Department of Skin Structural Studies, Chair of Cosmetology, School of Pharmacy with Division of Laboratory Medicine in Sosnowiec, \\ Medical University of Silesia, ul. Kasztanowa 3, 41-200 Sosnowiec, Poland \\ ${ }^{2}$ Chair and Department of Molecular Biology, School of Pharmacy with Division of Laboratory Medicine in Sosnowiec, \\ Silesian Medical University, ul. Jedności 8, 41-206 Sosnowiec, Poland \\ ${ }^{3}$ Department of Internal Medicine and Rheumatology, School of Medicine in Katowice, Medical University of Silesia, \\ ul. Ziołowa 45/47, 40-635 Katowice, Poland
}

Correspondence should be addressed to Dominika Wcisło-Dziadecka; ddziadecka@interia.pl

Received 11 September 2017; Revised 26 November 2017; Accepted 10 December 2017; Published 2 January 2018

Academic Editor: Marija Mostarica-Stojković

Copyright (C) 2018 Dominika Wcisło-Dziadecka et al. This is an open access article distributed under the Creative Commons Attribution License, which permits unrestricted use, distribution, and reproduction in any medium, provided the original work is properly cited.

\begin{abstract}
Objective. The aim of this study was to evaluate the influence of adalimumab on expression profile of genes associated with the histaminergic system in Normal Human Dermal Fibroblast (NHDF) cells stimulated with $8.00 \mu \mathrm{g} / \mathrm{ml}$ of adalimumab and the identification of miRNAs regulating these genes' expression. Methods. NHDFs were cultured with or without the presence of adalimumab for 2, 8, and 24 hours. The expression profile of genes and miRNA were determined with the use of microarray technology. Results. Among 22283 ID mRNA, 65 are associated with the histaminergic system. It can be observed that 15 mRNAs differentiate NHDFs cultures with adalimumab form control. The analysis of miRNAs showed that, among 1105 ID miRNA, 20 miRNAs are differentiating in cells treated with adalimumab for 2 hours, 9 miRNA after 8 hours, and only 3 miRNAs after 24 hours. Conclusion. It was also determined that miRNAs play certain role in the regulation of the expression of genes associated with the histaminergic system. The results of this study confirmed the possibility of using both genes associated with this system as well as miRNAs regulating their expression, as complementary molecular markers of sensitivity to the adalimumab treatment.
\end{abstract}

\section{Introduction}

Psoriasis is a chronic, immunological, inflammatory multifactorial skin disease which occurs in about 1-3\% of the population [1-3] and coexists often with a metabolic syndrome [46]. Psoriasis vulgaris is the most common form of dermatitis, occurring in $90 \%$ of cases. Psoriasis has a negative impact on the quality of life and well-being of patients, because of visible dermatological changes and persistent skin itching [1].

This disease is associated with a high concentration of proinflammatory cytokines, such as interleukins (IL-12, IL17, and IL-23), tumor necrosis factor $\alpha$ (TNF- $\alpha$ ), interferon
(IFN- $\gamma$ ), and transforming growth factor $\beta$ (TGF $\beta$ ), in serum and skin lesions as a consequence of the immune system activation [7-10].

One of the most important cytokines in the induction and development of an inflammatory process is TNF- $\alpha$, whose biological effects are mediated via two receptors, TNFR1 and TNFR2. In consequence, signaling pathways connected with this cytokine are activated. Increased secretion of TNF- $\alpha$ was observed in rheumatoid arthritis, ankylosing spondylitis, psoriasis, and inflammatory bowel disease [11-13].

In psoriasis, changes can be observed not only in mRNA expression, but also in miRNA profile. miRNAs (microRNAs) 
are a class of short and regulatory molecules of RNA that play an extremely important role in many human diseases. Currently, some miRNAs associated with skin and skin diseases including psoriasis have been identified and well described [14-17].

The high serum level of miR-1266 was observed in patients with psoriasis, highlighting its potential use as a biomarker [18]. In addition, the increased expression of miRNA-155, let-7i, miRNA-146a, miRNA-21, and miRNA223 in the mononuclear cells of peripheral blood and also miRNA-21, miRNA-146a, and miRNA-223 in plasma was noted [19]. Lerman et al. observed the expression of the following miRNAs in psoriatic lesion skin: hsa-miR-149, hsamiR-150, hsa-miR-210, hsa-miR-220, hsa-miR-326, has-miR324-5p, hsa-miR-342, hsa-miR-326, hsa-miR-328, hsa-miR345, hsa-miR-346, and hsamiR-197 [20].

One of the symptoms of psoriasis is skin itching, which can be associated with histamine secretion, mainly from immunocompetent cells, as a response to an inflammatory process. Histamine is a biogenic amine synthesized by decarboxylation of the amino acid L-histidine by histidine decarboxylase (HSD). Histamine is characterized as a mediator of a vast number of processes, such as inflammation, neurotransmission, physiological processes, smooth muscle contraction, and leukocyte chemotaxis. The biological effects of this amine are associated with its ability to interact with specific membrane receptors: $\mathrm{H} 1, \mathrm{H} 2, \mathrm{H} 3, \mathrm{H} 4$, and intracellular receptor Hic [21-23]. For example, the high concentration of histamine is observed in the respiratory system, skin, and gastric mucosal disorders. Only basophils and mast cells can store histamine in specific granules, from which it is released as a result of actions driven by various agents [11]. The histaminergic system not only consists of histamine and its receptors but also includes genes encoding proteins associated with transport and histamine metabolism, as well as genes encoding receptors participating in a signaling pathway activated by histamine.

Psoriasis is mainly treated by retinoids, cyclosporine A, and biological drugs. Biological medicines constitute a group of biologically active substances, typical proteins, and peptides, obtained with the application of molecular biology techniques and genetic engineering. The understanding of the pathomechanism inducing various diseases has created the possibility of developing drugs, the mechanism of action of which involves blocking the metabolic or signaling pathways that play a critical role in the disease development [24].

Adalimumab is a biological medicine, one of the three anti-TNF drugs used in the psoriasis vulgaris and psoriasis arthritis treatment [25]. This type of therapy is called a biological therapy, to be used in patients who have failed conventional treatment $[26,27]$. This medicine is known as a fully human monoclonal antibody, which neutralizes tumor necrosis factor $\alpha$ (TNF- $\alpha)$. Adalimumab has an ability of binding to free and membrane-bound form of TNF- $\alpha$, which prevents the interaction of TNF- $\alpha$ and receptors: TNFR1 and TNFR2; therefore, signaling pathways are blocked [28].

The aim of this study was to evaluate the influence of adalimumab on the expression profile of genes associated with the histaminergic system in Normal Human Dermal Fibroblast
(NHDF) cells stimulated with $8.00 \mu \mathrm{g} / \mathrm{ml}$ of adalimumab for 2,8 , and 24 hours and the identification of variously expressed genes whose transcriptional activity significantly differs.

\section{Materials and Methods}

2.1. Cell Culture. The NHDF cell line (fourth passage) was cultured in the FBM medium (Fibroblast Basal Medium; Lonza, Basel, Switzerland), supplemented with hFGF-B (Human Fibroblast Growth Factor-Basic) and insulin and gentamicin $\left(\mathrm{FGM}^{\mathrm{TM}}\right.$ SingleQuots ${ }^{\mathrm{TM}}$; Lonza, Basel, Switzerland) at $37^{\circ} \mathrm{C}$ in a $5 \% \mathrm{CO}_{2}$ incubator (Direct Heat $\mathrm{CO}_{2}$; Thermo Scientific, Waltham, MA, USA). The quantity of cells and their viability were monitored by cell counting in the Bürker chamber after staining them with $0.2 \%$ trypan blue (Biological Industries, Beit HaEmek, Israel). To test the effects of the drug on gene expression, $8 \mu \mathrm{g} / \mathrm{ml}$ of adalimumab (AbbVie Biotechnology $\mathrm{GmbH}$, Knollstrasse, Germany) was added to the cell culture for 2, 8, and 24 hours. Control cells were not treated with adalimumab. The concentration was customized to the level of adalimumab in the bodies of psoriatic patients.

2.2. Cytotoxicity Assay. An evaluation of the cytotoxicity of anti-TNF drug in NHDF cells was performed using the XTT assay (In Vitro Toxicology Assay Kit, XTT based; SigmaAldrich, St Louis, MO, USA).

The following range of adalimumab concentrations was used in the cytotoxicity test: $0.08 \mu \mathrm{g} / \mathrm{ml}, 0.8 \mu \mathrm{g} / \mathrm{ml}, 8 \mu \mathrm{g} / \mathrm{ml}$, $80 \mu \mathrm{g} / \mathrm{ml}$, and $800 \mu \mathrm{g} / \mathrm{ml}$, whereas the control sample involved the NHDF culture, which was not exposed to the drug. The following average absorbances were generated for the individual concentrations: $0.08 \mu \mathrm{g} / \mathrm{ml}-0.079125 ; 0.8 \mu \mathrm{g} /$ $\mathrm{ml}-0.086625 ; \quad 8 \mu \mathrm{g} / \mathrm{ml}-0.08475 ; \quad 80 \mu \mathrm{g} / \mathrm{ml}-0.014375$; $800 \mu \mathrm{g} / \mathrm{ml}-0.023$; control sample-0.087.

The statistical analysis of the XTT assay was performed with the use of Statistica 13.0 PL (StatSoft, Tulsa, Oklahoma, USA), assuming the statistical gravity factor $p<0.05$. The statistical analysis involved Shapiro-Wilk data distribution normality tests, which was confirmed $(p>0.05)$ and then an ANOVA variance test was performed. Within the concentrations ranging from $0.08 \mu \mathrm{g} / \mathrm{ml}$ to $8.00 \mu \mathrm{g} / \mathrm{ml}$ no cytotoxic effect of the substance was observed on NHDF cells $(p<$ $0.05)$, in turn, for adalimumab concentrations, $80 \mu \mathrm{g} / \mathrm{ml}$ and $800 \mu \mathrm{g} / \mathrm{ml}$, a cytotoxic effect was observed when compared with the control sample; thus, the post hoc Tukey's test was conducted $(80 \mu \mathrm{g} / \mathrm{ml}$ versus C, $p=0.000141 ; 800 \mu \mathrm{g} / \mathrm{ml}$ versus $C, p=0.000141)$.

2.3. Extraction of Total RNA. Total RNA was extracted from cells with the use of TRIzol reagent (Invitrogen Life Technologies, Carlsbad, CA, USA), according to the manufacturer's protocol. Extracts of total RNA were purified using the RNeasy Mini Kit (QIAGEN, Hilden, Germany) and treated with DNAse I (Fermentas International Inc., Burlington, ON, Canada), according to the manufacturer's instructions. The RNA concentration was determined with the use of a Gene Quant II spectrophotometer (Pharmacia LKB Biochrom Ltd., Cambridge, UK). 
TABLE 1: The results of the one-way ANOVA test with the Benjamini-Hochberg multiple testing correction.

\begin{tabular}{ccccccc}
\hline Corrected $p$ value & $p$ all & $p<0.05$ & $p<0.02$ & $p<0.01$ & $p<0.005$ & $p<0.001$ \\
\hline 65 & 15 & 11 & 10 & 7 & 5 \\
\hline
\end{tabular}

2.4. Oligonucleotide Microarray Analysis. The analysis of expression profile of genes associated with the histaminergic system was performed using commercially available oligonucleotide microarrays HG-U133A_2 (Affymetrix, Santa Clara, CA), according to the manufacturer's recommendations. Each gene chip contains 22238 probe sets that correspond to more than 18400 transcripts and 14500 well-characterized human genes.

About $8 \mu \mathrm{g}$ of total RNA was used for the cDNA synthesis using SuperScript Choice System (Gibco BRL Life Technologies). During the next step, cDNA was used as a template to produce biotin-labeled cRNA using BioArray HighYield RNA Transcript Labeling Kit (Enzo Life Sciences, NY). cRNA was then purified on RNeasy Mini Kit columns (Qiagen, Gmbh, Hilden, Germany). The biotin-labeled cRNA was fragmented using Sample Cleanup Module (Qiagen) and hybridized with the HG-U133A_2 microarray (Affymetrix). The cRNA hybridized to oligonucleotide arrays was stained with streptavidin-phycoerythrin conjugate and was scanned using GeneArray Scanner G2500A (Agilent Technologies, CA). The scanned data were processed for signal values using Microarray Suite 5.0 software (Affymetrix).

2.5. miRNA Microarray Analysis. The analysis of expression profile of miRNAs responsible for regulation of histaminerelated genes was performed using commercially available GeneChip miRNA 2.0 Array (Affymetrix, Santa Clara, CA). The first step involved the labeling of miRNA with biotin by polyadenylation and ligation. The evaluation of labeling efficiency was verified using ELOS QC Assay (FlashTagBiotin HSR RNA Labeling Kit, Affymetrix). Subsequently, the hybridization of labelled RNA molecules of the microarray and probes was scanned using GeneArray Scanner 3000 7G (Agilent Technologies, CA). The scanned data were processed for signal values using Microarray Suite 5.0 software (Affymetrix).

2.6. Statistical Analysis. Agilent GeneSpring GX software was used for statistical analysis of the data after microarrays scanning. Differentially expressed genes were determined using one-way ANOVA (analysis of variance) test with asymptotic $p$ values. The criteria used for differentially expressed genes required the absolute value of Fold Change (FC) to be greater than $1(|\mathrm{FC}|>1)$ in at least one compared paired samples. The standard cut-off of $p$ value $<0.05$ was set to determine statistical significance of mRNA fluorescent signals.

The microarray data analysis was performed with the use of the GeneSpring 12.6.1 platform (Agilent Technologies, Inc., Santa Clara, CA, USA) and PL-Grid Infrastructure. In order to determine which of the differentiating miRNAs of the fibroblast cells exposed to the drug, compared to the control sample, could potentially affect the transcriptional activity of the differentiating mRNAs, the miRNA target prediction tools mirTAR (http://mirtar.mbc.nctu.edu.tw/ human/predictionIndex.php) and microRNA.org (http:// www.microrna.org/microrna/getGeneForm.do) have been used.

\section{Results}

3.1. Cytotoxicity Assay. The XTT assay revealed that no cytotoxicity was observed in NHDF cells after the adalimumab exposure for 2, 8, and 24 hours.

3.2. Transcriptome Analysis of NHDF Treated with Adalimumab. The names of the probes were obtained from Affymetrix NetAffxTM Analysis Center database (http://www .affymetrix.com/analysis/index.affx) on 20.09.2016. From 22 283 ID mRNA which are presented in the HG-U133A microarrays (Affymetrix), 65 are associated with the histaminergic system.

The first stage involved a one-way ANOVA testing with a Benjamini-Hochberg multiple testing correction, which showed 15 differentiating transcripts of histaminergic system genes $(p<0.05$; Table 1$)$.

Tukey's post hoc analysis test was used to identify differences in gene expression between the individual groups. In order to identify differentially expressed genes in cells treated with adalimumab, compared to the control group, the Tukey HSD post hoc test $(P<0.05$ and FC $\geqslant 1.0)$ was performed. It indicated $4 \mathrm{mRNAs}$ with differentiable levels of expression between the control group (C) and the group consisted of cells exposed to adalimumab for 8 hours. Four mRNAs with differentiable levels of expression were identified between the control group (C) and the group of 24-hour samples. Additionally, 10 mRNAs with differentiable levels of expression were found between the control group (C) and the group of cells treated for 2 hours with adalimumab (Table 2).

A heat map was generated to assess the differences of the expression of 15 transcripts in individual groups (Figure 1). Table 3 shows the changes.

A Venn diagram was drawn up to identify genes common to all the groups of transcriptomes and characteristic only for a particular group (Figure 2).

The analysis of Venn diagram showed that adalimumab changes the expression of 7 mRNAs encoded by 6 genes after 2 hours of stimulation of NHDF cells with the drug (VAMP2, HNMT, ADA, HRH1, DIAPH1, and HNMT), 4 mRNAs encoded by 3 genes after 8-hour stimulation (EDNRA, EDN1, and SLC22A3) with only one gene (SLC22A3) specific to cells treated with adalimumab for 8 hours. There were also changes in the expression of 4 mRNAs encoded by 4 genes after 24 hours of adalimumab stimulation (SNX4, GABRA1, DRD2, and LYN) (Table 4). 
TABLE 2: The Tukey HSD post hoc test results showing differentiating transcripts for cells treated with adalimumab in comparison to control cells.

\begin{tabular}{lcccc}
\hline Group name & Control & $8 \mathrm{~h}$ & $24 \mathrm{~h}$ & \\
\hline Control & 15 & 4 & 4 & $2 \mathrm{~h}$ \\
$8 \mathrm{~h}$ & 11 & 15 & 8 & 10 \\
$24 \mathrm{~h}$ & 13 & 10 & 15 & 11 \\
$2 \mathrm{~h}$ & 5 & 4 & 1 & 14 \\
\hline
\end{tabular}

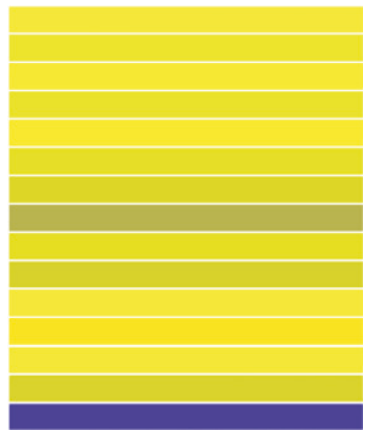

$[\mathrm{C}]$

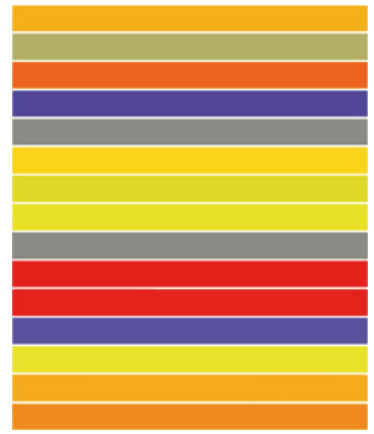

[T_2]

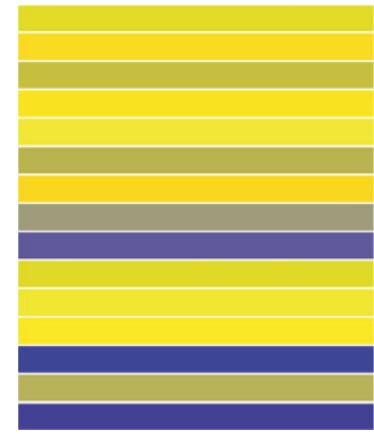

[T_24]

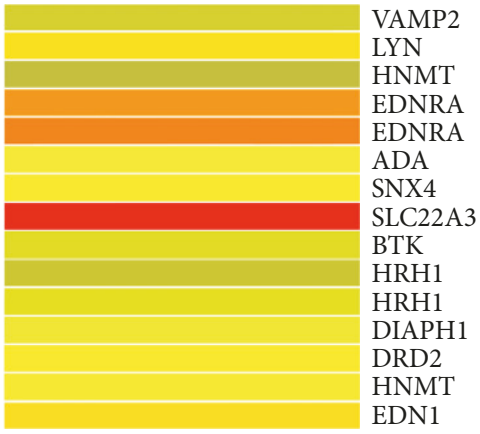

[T_8]

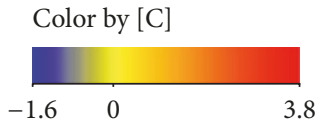

FIGURE 1: Heat map of fluorescence signal intensities of 15 mRNA IDs of genes associated with the histaminergic system (blue, the lowest value; red, the highest value of fluorescence signals; T_2, T_8, and T_24, study groups; C, control group).

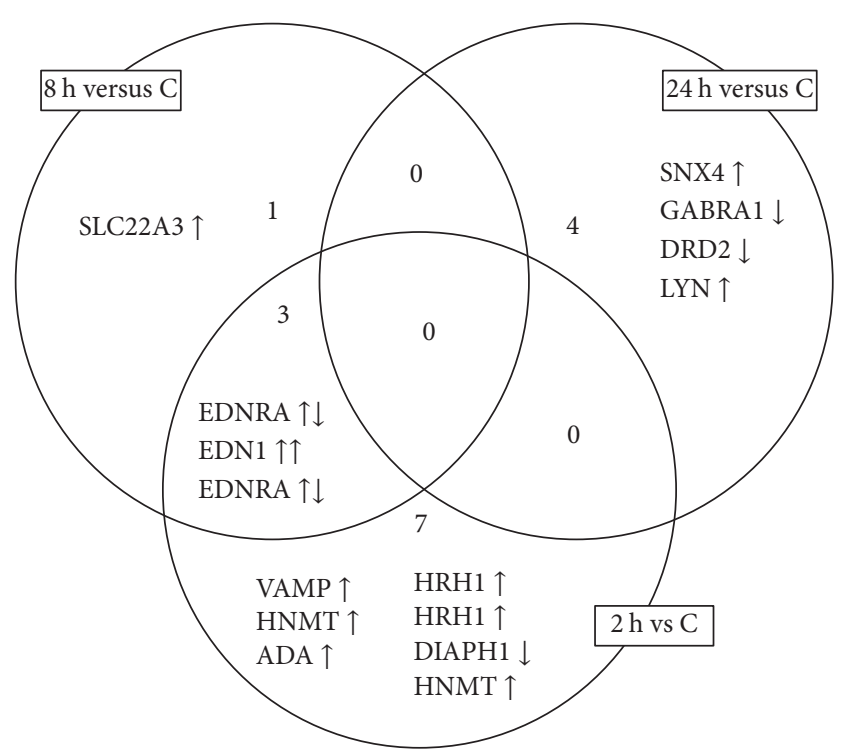

Figure 2: The Venn diagram of microarray results $(p<0.05)$.

3.3. miRNA Microarray Analysis of NHDF Cells Treated with Adalimumab. The bioinformatic resources of the miRTar database have allowed to determine which of the differentiating microRNAs correlated to the mRNAs differentiating the fibroblasts exposed to the drug from the control group. Based on the miRNA SVR score parameter obtained from the microRNA database, the correlation between the respective
miRNA molecule and the mRNA sequence of a gene was determined. The cut-off of -0.1 or lower is used as the cutoff point for this parameter based on the data from literature.

The microarray analysis in normal human skin fibroblast cells exposed for 2 hours with the anti-TNF drug revealed 20 miRNAs differentiating NHDF cells stimulated with adalimumab, compared to the control culture of dermal fibroblasts, but only 12 of them have connection with differentiating mRNAs.

An analysis of 8-hour exposure of fibroblasts to adalimumab revealed 9 differentiating miRNAs, but only one of them is connected with differentiating mRNA. We observed a connection between miR-1909 and gene encoding endothelin-1. The analysis showed increased expression of miRNA and EDN1.

After 24 hours of the experiment, 3 miRNAs were identified as differentiating, but none of them showed any connection with differentiating mRNAs (Table 5 and Figure 3).

\section{Discussion}

Biological drugs are currently used to treat many diseases, such as psoriatic arthritis, psoriasis vulgaris, or Crohn's disease [29-32].

Adalimumab is a biological medicine, one of the three anti-TNF drugs used in the treatment of psoriasis vulgaris and psoriasis arthritis [25].

The results of described experiment show that the expression profile of genes associated with histamine activity is different in Normal Human Dermal Fibroblast (NHDF) cells 
TABLE 3: Transcripts of genes associated with the histaminergic system, differentiating the response of adalimumab treatment on NHDF cells, compared with the control samples.

\begin{tabular}{|c|c|c|c|c|c|c|c|}
\hline ID & Gene symbol & $\begin{array}{c}2 \text { hours } \\
\text { (up/down) }\end{array}$ & $\begin{array}{c}\text { FC } \\
\text { (2 hours versus } \\
\text { C) } \\
\end{array}$ & $\begin{array}{l}24 \text { hours } \\
\text { (up/down) }\end{array}$ & $\begin{array}{c}\text { FC } \\
\text { (24 hours versus } \\
\text { C) }\end{array}$ & $\begin{array}{c}8 \text { hours } \\
\text { (up/down) }\end{array}$ & $\begin{array}{c}\text { FC } \\
(8 \text { hours } \\
\text { versus } \mathrm{C}) \\
\end{array}$ \\
\hline 201557_at & VAMP2 & Up & 1.3076547 & Down & -1.037129 & Down & -1.0554649 \\
\hline 202625_at & LYN & Down & -1.0955737 & Up & 1.1316916 & Up & 1.1089189 \\
\hline 204112_s_at & HNMT & $\mathrm{Up}$ & 1.6368151 & Down & -1.1016508 & Down & -1.1010625 \\
\hline 204463_s_at & EDNRA & Down & -1.226046 & Up & 1.09312 & Up & 1.4448898 \\
\hline 204464_s_at & EDNRA & Down & -1.2038972 & Down & -1.0421386 & Up & 1.4517964 \\
\hline 204639_at & $\mathrm{ADA}$ & $\mathrm{Up}$ & 1.1746593 & Down & -1.0697097 & Up & 1.0407584 \\
\hline 205329_s_at & SNX4 & Up & 1.0058819 & Up & 1.1812408 & Up & 1.0806441 \\
\hline 205421_at & SLC22A3 & Up & 1.0740671 & Down & -1.0358303 & Up & 2.274354 \\
\hline 206678_at & GABRA1 & Down & -1.1993337 & Down & -1.282568 & Down & -1.0323519 \\
\hline 205579_at & HRH1 & Up & 2.4778538 & Up & 1.0098535 & Down & -1.0161992 \\
\hline 205580_s_at & HRH1 & Up & 2.3650975 & Down & -1.0148736 & Down & -1.0308013 \\
\hline 209190_s_at & DIAPH1 & Down & -1.3211001 & Down & -1.0192791 & Down & -1.082756 \\
\hline 211624_s_at & DRD2 & Down & -1.0191133 & Down & -1.36553 & up & 1.0382545 \\
\hline 211732_x_at & HNMT & Up & 1.3924775 & Down & -1.0599645 & up & 1.0668004 \\
\hline 218995_s_at & EDN1 & Up & 1.8715541 & Down & -1.0243433 & up & 1.3998785 \\
\hline
\end{tabular}

TABLE 4: The changes of the mRNA expression in cells treated with adalimumab.

\begin{tabular}{|c|c|c|c|c|}
\hline ID & Gene name & Encoded protein name & Group & Change \\
\hline 201557_at & VAMP2 & Vesicle associated membrane protein 2 & $2 \mathrm{~h}$ versus $\mathrm{C}$ & Up \\
\hline 204112_s_at & HNMT & Histamine N-methyltransferase & $2 \mathrm{~h}$ versus $\mathrm{C}$ & Up \\
\hline 204639_at & $\mathrm{ADA}$ & Adenosine deaminase & $2 \mathrm{~h}$ versus $\mathrm{C}$ & Up \\
\hline 205579_at & HRH1 & Histamine receptor $\mathrm{H} 1$ & $2 \mathrm{~h}$ versus $\mathrm{C}$ & Up \\
\hline 205580_s_at & HRH1 & Histamine receptor $\mathrm{H} 1$ & $2 \mathrm{~h}$ versus $\mathrm{C}$ & Up \\
\hline 209190_S_at & DIAPH1 & Diaphanous related formin 1 & $2 \mathrm{~h}$ versus $\mathrm{C}$ & Down \\
\hline 211732_x_at & HNMT & Histamine N-methyltransferase & $2 \mathrm{~h}$ versus $\mathrm{C}$ & Up \\
\hline 205421_at & SLC22A3 & Solute carrier family 22 member 3 & $8 \mathrm{~h}$ versus $\mathrm{C}$ & Up \\
\hline 204463_s_at & EDNRA & Endothelin receptor type A & $8 \mathrm{~h}$ versus $\mathrm{K}$ i $2 \mathrm{~h}$ versus $\mathrm{C}$ & Up/down \\
\hline 204464_s_at & EDNRA & Endothelin receptor type A & $8 \mathrm{~h}$ versus $\mathrm{K}$ i $2 \mathrm{~h}$ versus $\mathrm{C}$ & Up/down \\
\hline 218995_s_at & EDN1 & Endothelin 1 & $8 \mathrm{~h}$ versus $\mathrm{K}$ i $2 \mathrm{~h}$ versus $\mathrm{C}$ & Up/up \\
\hline 205329_s_at & SNX4 & Sorting nexin 4 & $24 \mathrm{~h}$ versus $\mathrm{C}$ & Up \\
\hline 206678_at & GABRA1 & Gamma-aminobutyric acid (GABA) A receptor, alpha 1 & $24 \mathrm{~h}$ versus $\mathrm{C}$ & Down \\
\hline 211624_s_at & DRD2 & Dopamine receptor D2 & $24 \mathrm{~h}$ versus $\mathrm{C}$ & Down \\
\hline 202625_at & LYN & LYN proto-oncogene & $24 \mathrm{~h}$ versus $\mathrm{C}$ & Up \\
\hline
\end{tabular}

treated with adalimumab and in the control cells. Moreover, it was observed that differences in expression depend on the drug exposure time. The highest amount of mRNA that differentiated normal human skin fibroblast exposed to antiTNF drug was observed after 2 hours of drug stimulation. The number of differentiating transcripts decreased with the prolongation of the incubation time of skin fibroblasts with the drug. The ability to observe molecular changes that indicate cell sensitivity of skin fibroblasts after 2 hours following drug administration suggests the possibility of the application of genes associated with histaminergic system as complementary markers of the response to treatment.

In the authors' judgment, searching for potential markers that do not involve only blocking the signaling pathway of
TNF by adalimumab will allow for greater precision and accuracy to monitor the effectiveness of therapy and to detect the lack of sensitivity of the cells to the drug at an early stage. In addition, it is important to remember that molecular changes precede phenotypic changes, which emphasizes the need to find new markers to change the treatment before the patient exhibits adverse changes in the phenotype.

As far as we are aware, this is the first study concerning both the regulation of transcriptional activity and changes in expression of genes associated with the histaminergic system in NHDH cells treated with adalimumab. We also assessed the miRNAs expression in the same conditions. Our aim was to find the relationship between genes of the histaminergic system and miRNAs that regulate these. 
TABLE 5: The miRNA microarray analysis of NHDF cells treated with adalimumab versus control group.

\begin{tabular}{|c|c|c|c|c|c|c|}
\hline Compared groups & ID & Name & FC & Change & Gene & SVR score \\
\hline $2 \mathrm{~h}$ versus $\mathrm{C}$ & hsa-miR-1231_st & hsa-mir-1231 & 2,24 & Up & EDNRA & $-0,2007$ \\
\hline \multirow{5}{*}{$2 \mathrm{~h}$ versus $\mathrm{C}$} & \multirow{5}{*}{ hsa-miR-1275_st } & \multirow{5}{*}{ hsa-mir-1275 } & \multirow{5}{*}{$-2,39$} & \multirow{5}{*}{ down } & $\mathrm{ADA}$ & N/A \\
\hline & & & & & HRH1 & $-0,5925$ \\
\hline & & & & & EDN1 & $-0,8504,-0,6048$ \\
\hline & & & & & DIAPH1 & $-0,0025$ \\
\hline & & & & & VAMP2 & $-0,2280$ \\
\hline $2 \mathrm{~h}$ versus $\mathrm{C}$ & hsa-miR-143_st & hsa-mir-143 & 2,21 & Up & DIAPH1 & $-0,1193$ \\
\hline $2 \mathrm{~h}$ versus $\mathrm{C}$ & hsa-miR-16_st & hsa-miR-16 & 2,17 & Up & EDNRA & $-0,0062,-0,0299$ \\
\hline \multirow{3}{*}{$2 \mathrm{~h}$ versus $\mathrm{C}$} & \multirow{3}{*}{ hsa-miR-1909-star_st } & \multirow{3}{*}{ hsa-mir-1909 } & \multirow{3}{*}{2,86} & \multirow{3}{*}{ Up } & EDN1 & $-0,2846$ \\
\hline & & & & & DIAPH1 & $-0,4198$ \\
\hline & & & & & VAMP2 & $-0,2332$ \\
\hline $2 \mathrm{~h}$ versus $\mathrm{C}$ & hsa-miR-196a_st & hsa-miR-196a & 3,13 & Up & EDN1 & $-0,384$ \\
\hline $2 \mathrm{~h}$ versus $\mathrm{C}$ & hsa-miR-199a-5p_st & hsa-miR-199a-5p & 3,49 & Up & DIAPH1 & $-0,0020$ \\
\hline $2 \mathrm{~h}$ versus $\mathrm{C}$ & hsa-miR-22_st & hsa-mir-22 & 3,04 & Up & EDNRA & $-0,0720$ \\
\hline \multirow{2}{*}{$2 \mathrm{~h}$ versus $\mathrm{C}$} & \multirow{2}{*}{ hsa-miR-3162_st } & \multirow{2}{*}{ hsa-mir-3162 } & \multirow{2}{*}{2,07} & \multirow{2}{*}{ Up } & EDNRA & $-0,0102$ \\
\hline & & & & & VAMP2 & $-0,7142$ \\
\hline \multirow{2}{*}{$2 \mathrm{~h}$ versus $\mathrm{C}$} & \multirow{2}{*}{ hsa-miR-34a_st } & \multirow{2}{*}{ hsa-mir-34a } & \multirow{2}{*}{6,52} & \multirow{2}{*}{ Up } & HRH1 & $-0,0024,-0,0017$ \\
\hline & & & & & VAMP2 & $-0,7881$ \\
\hline $2 \mathrm{~h}$ versus $\mathrm{C}$ & hsa-miR-382_st & hsa-mir-382 & 2,82 & Up & HNMT & $-0,3818$ \\
\hline $2 \mathrm{~h}$ versus $\mathrm{C}$ & hsa-miR-939_st & hsa-mir-939 & 2,17 & Up & VAMP2 & $-0,9181$ \\
\hline $8 \mathrm{~h}$ versus $\mathrm{C}$ & hsa-miR-1909-star_st & hsa-mir-1909 & 2,79 & Up & EDN1 & $-0,2846$ \\
\hline
\end{tabular}

The most characteristic clinically observed symptom of psoriasis is parakeratosis (incomplete keratinization) caused by an abnormal proliferation and differentiation of keratinocytes in the basal layer of the skin [33-35].

The study of Gschwandtner et al. shows that histamine plays an important role in proinflammatory processes and deregulation of keratinocyte differentiation and impairs skin barrier in in vitro study model [36]. A higher concentration of this biogenic amine in psoriasis is associated with an activation and increased number of immune system cells, such as B lymphocytes, T lymphocytes, mast cells that can secrete proinflammatory cytokines, or other inflammatory compounds, for instance, TNF- $\alpha$, interleukins, and also histamine [7-9]. The impact of histamine in inflammation was noted by Ruzicka and Glück who observed that after degranulation of mast cells, the tissue level of histamine can rise to $10-1000 \mu \mathrm{M}$ [37]; also the higher concentration of this compound was reported in patients with atopic dermatitis [38].

In this study, the following transcripts differentiating the NHDF cells treated with adalimumab in comparison to the control samples can be observed: VAMP (vesicle associated membrane protein 2), HNMT (histamine N-methyltransferase), $A D A$ (adenosine deaminase), $H R H 1$ (histamine receptor H1), DIAPH1 (diaphanous related formin 1), HNMT (histamine N-methyltransferase), SLC22A3 (solute carrier family 22 member 3), EDNRA (endothelin receptor type A), EDN1 (endothelin), SNX (sorting nexin 4), GABRA1 (gamma-aminobutyric acid (GABA) A receptor, Alpha 1),
DRD2 (dopamine receptor D2), and LYN (LYN protooncogene, Src family tyrosine kinase). The highest number of differentiating mRNAs was observed after 2 hours of cells stimulation with drug, which may indicate the speed of drug action and the effect on genes expression.

This study focused on identifying the expression of genes associated with the histaminergic system in NHDF cells cultured in the presence of adalimumab $(8 \mu \mathrm{g} / \mathrm{ml})$ for 2,8 , and 24 hours compared to control cells. After 2 hours of drug exposure, compared to the control sample, we observed changes in the expression pattern of the following genes: VAMP2 (upregulated), DIAPH1 (downregulated), HNMT (upregulated), HRH1 (upregulated), HRH1 (upregulated), and $A D A$ (upregulated).

VAMP2 was described as a gene encoding protein, associated with the neurotransmitter transport. Honardoost et al. analysed the role of VAMP2 as one of the potential markers in an insulin resistance process. This hypothesis relied on the observation that VAMP2 is essential in delivery of GLUT4 (glucose transporter type 4) to the plasma membrane. [39]. In this study, it can be observed that the change of VAMP2 expression is statistically significant in NHDF cells after 2hour exposure to adalimumab, in comparison to the control cultures.

DIAPH1 is one of the three gene isoforms encoding mammalian diaphanous-related formins. Pan et al. indicate that DIAPH1 is involved in megakaryocyte proplatelet formation, associated with remodelling either the actin or microtubule 

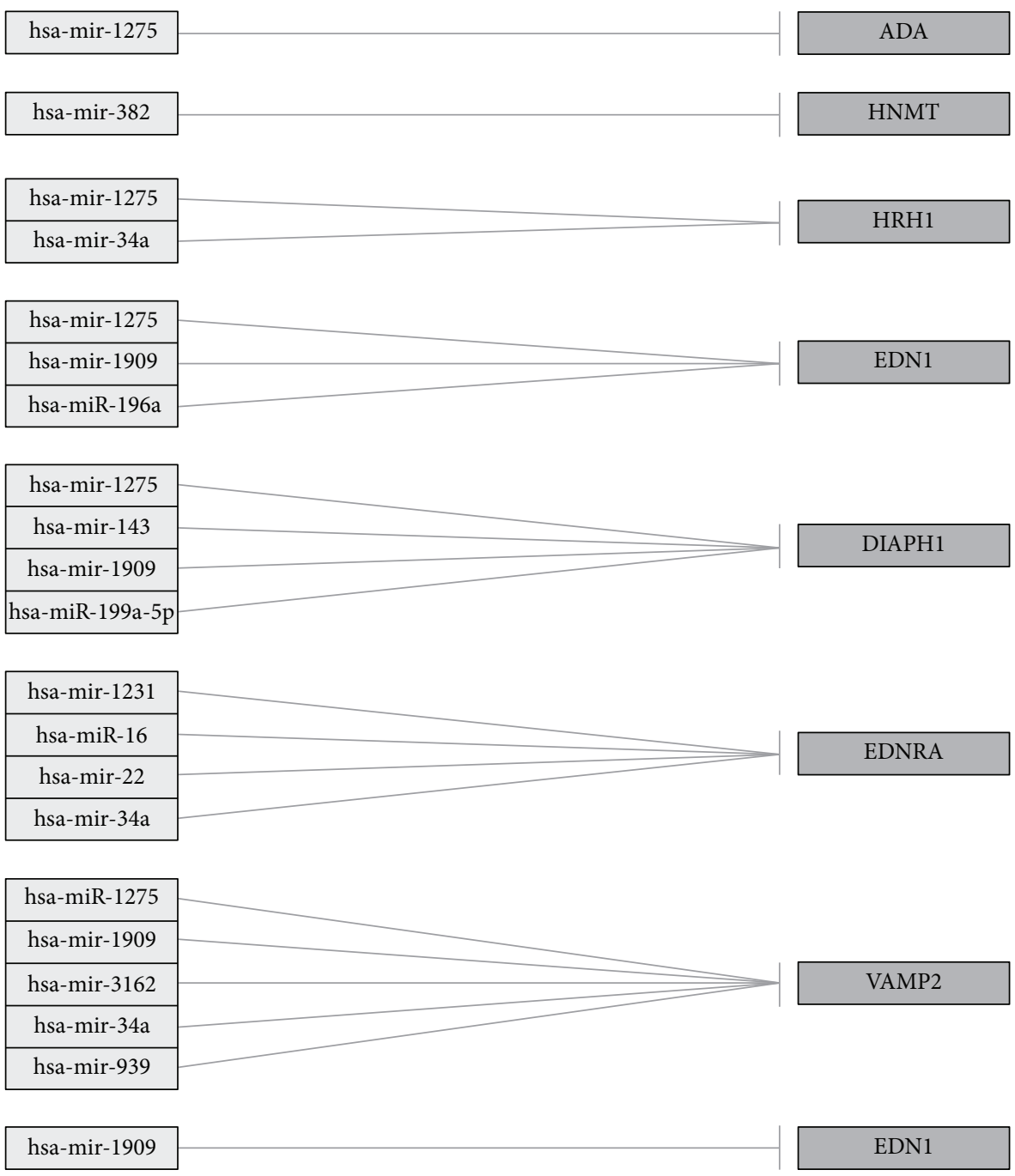

Figure 3: All miRNAs affecting the transcriptional activity of genes differentiating NHDF cells after 2 and 8 hours of stimulation with adalimumab from the control cells.

cytoskeletons [40]. Lin et al. observed the higher expression level of this gene in colorectal cancer and downregulation of transcriptional activity in colon carcinoma cells [41].

In this study, the effect of adalimumab on genes encoding proteins associated with metabolism of histamine, HNMT (histamine $N$-methyltransferase), and histamine receptor $\mathrm{H} 1$, $H R H 1$, can be observed.

The transcriptional activity of HNMT in NHDF cells after 2 hours of stimulation with adalimumab was higher than in nonstimulated cells. This gene encodes histamine Nmethyltransferase involved in the biotransformation of histamine. Our study shows that adalimumab can influence the histaminergic system, reducing histamine concentration by increasing the expression of genes involved in its degradation.

The second gene directly associated with the histaminergic system is HRH1. Stimulation of this receptor by interacting with histamine leads to an activation of phospholipase C, inositol 1,4,5-triphosphate and diacylglycerol, protein kinase $\mathrm{C}$, and $\mathrm{Ca}^{2+}$ [42]. HRH1 plays a fundamental role in the occurrence symptoms of immediate-type allergic reactions, activating nuclear factor $\kappa \mathrm{B}(\mathrm{NF} \kappa \mathrm{B})$ and, in consequence, increasing the antigen-presenting capacity of the cells, expression of proinflammatory cytokines, and chemotactic factors [43]. The higher level of $H R H 1$ in cells treated with adalimumab, when compared to control cells, can be connected with an activation of immune mechanisms by the biological drug.

This study also shows that the higher mRNA concentration level of $A D A$ (adenosine deaminase), the gene encoding an enzyme involved in purine metabolism, catalysing hydrolysis of adenosine to inosine, can be observed after 2 hours of cells stimulation [44]. This enzyme plays a key role in the proliferation, maturation, and differentiation of lymphocytes and regulates adenosine concentration in blood plasma [45]. The higher level of $A D A$ observed in this study may suggest the increased amounts of adenosine in NHDF cells after 2 hours of exposure to adalimumab as a result of ATP (adenosine triphosphate) degradation. 
The statistical analysis shows that only SLC22A3 (solute carrier family 22 member 3) constitutes a statistically significant differentiating gene in the group of cells after 8 hours of exposure to adalimumab, in comparison to control cultures. It is believed that adalimumab can change transcriptional activity of SLC22A3 (upregulated after 8 hours). This gene encodes transmembrane protein OCT3 (organic cation transporter 3), which plays an extremely important role in the outward transport of bioamines and some drugs, for example, metformin, histamine, and dopamine. [46-48].

The study of $\mathrm{Li}$ et al. have shown that deficiency of SLC22A3 expression tends to increase the intracellular concentration of histamine [48].

Our data on expression profile of this gene may suggest that adalimumab decreases the level of histamine in cells after 2 and 8 hours of drug exposure; however, after 24 hours the amount of biogenic amines may be increased.

The study demonstrates that EDNRA (endothelin receptor type A) and EDN1 (endothelin-1) transcripts are differentiating after 2 and 8 hours of exposure to adalimumab, when compared to control. After 2 hours, both EDN1 and EDNRA were overexpressed; on the other hand, after 8 hours the transcriptional activity of EDNRA was reduced.

Endothelin-1 is the most representative member of the endothelin family. It is known as a very strong vasoconstrictor factor, proliferation stimulator [49]. The interaction between endothelin-1 and endothelin receptor type A results in the activation of signaling pathways associated with apoptosis, angiogenesis, and cancerogenesis [50-53]. The expression pattern of EDN1 and its receptor EDNRA may be explained by the anti-inflammatory properties shown by adalimumab. One of the functions of histamine is to increase the vascular permeability; thus, it can be observed after NHDF cells stimulation with adalimumab that genes associated with the opposite process to the one described, namely, the vasoconstrictor process, are overexpressed. The higher expression of these genes after 2 hours may also be caused by the secretion of endothelin from mast cell as a response to changes in the immunologic system after adalimumab administration.

Four genes, DRD2, GABRA1, SNX4, and LYN, are differentiating in NHDF cells treated with the drug, in comparison to control cultures. The changes in expression pattern of DRD2 (dopamine receptor D2) suggest the interaction between the histaminergic and dopaminergic systems and a complex effect of adalimumab on gene expression. In this study, the transcriptional activity of the gene in NHDF cells was downregulated after 24 hours of stimulation, when compared with control cell cultures.

After 24 hours of exposure to adalimumab, changes in the expression pattern of GABRA1, encoding gammaaminobutyric acid type A receptor alpha 1 subunit, can be observed in NHDF cells. The results of the study show a decrease in the transcriptional activity of the said gene. Similar result was observed in brain samples taken from patients with multiple sclerosis [54]. The second differentiating gene after 24 hours was SNX4 (sorting nexin 4), which, according to the Gene of NCBI (National Center for Biotechnology Information) database, encodes protein involved in the phosphoinositide transport.
It is demonstrated that the histaminergic system is complicated and not only consists of histamine and its receptors but also includes genes encoding proteins associated with the transport and metabolism of the amine and genes encoding receptors participating in signaling pathway activated by histamine. The results of changes in the transcriptional activity observed in this study indicate that genes associated with histaminergic system can be used as new markers of response to treatment with anti-TNF drug: adalimum$\mathrm{ab}$.

In this study, an attempt was made to select miRNAs regulating the transcriptional activity of genes associated with the histaminergic system in Normal Human Dermal Fibroblast (NHDF) cells exposed to adalimumab.

miRNA plays an important role in posttranscriptional regulation of gene expression, participating in many important physiological processes, including development, cell differentiation, and regulation of signaling pathways [55]. The participation of these molecules is emphasized in pathological conditions, for example, in tumors $[55,56]$, neurological disorders [56], and psoriasis [18].

miRNAs are a new group of biomarkers used to detect, predict, and monitor the effects of treatment in many diseases [57-60], which is determined by the high stability of these particles and the universality of their occurrence in body fluids, including blood, saliva, urine, and breast milk [61].

The study on the coexpression of miRNA and genes associated with the histaminergic system showed occurring several dependencies.

The ability of the miRNA to negatively regulate the transcriptional activity of a gene was determined by the miRNA SVR score. Based on the data for available literature, the cutoff value of this parameter is -0.1 or lower, because, for scores closer to zero, the probability of significant downregulation decreases, while the number of predictions increases rapidly [62].

The incubation of NHDF cell cultures for 2 hours with a biological drug leads to changes in the expression of 12 miRNAs (hsa-miR-1231, hsa-miR-1275, hsa-miR-143, hsamiR-16, hsa-miR-1909, hsa-miR-196a, hsa-miR-199a-5p, hsamiR-22, hsa-miR-3162, hsa-miR-34a, hsa-miR-382, and hsamiR-939), regulating the expression of the analysed transcripts. The analysis also showed that a single miRNA may be involved in expression regulation of more than one mRNA transcript. This situation is observed during the 2-hour incubation of the cells with the drug for three miRNAs: hsamiR-1275, which posttranscriptionally regulates the activity of following mRNAs: ADA, HRH1, EDN1, DIAPH1, and VAMP2; hsa-miR-34a: EDNRA, VAMP2, and HRH1; hsamiR-1909: VAMP2 and DIAPH1.

In our studies, we have observed that after 2-hour incubation of the cells with adalimumab, hsa-miR-22 is involved in the regulation of EDNRA expression. The data from the experiment show the overexpression of both hsa-miR-22 and EDNRA mRNA. Krintel et al. have demonstrated that miR22 may be a useful diagnostic marker used to monitor the results of adalimumab therapy. Downregulation of mir-22 expression with simultaneous overexpression of miR-886.3p suggests the effectiveness of the treatment, while a reverse 
profile of these two miRNAs may be a negative prognostic marker in a pharmacotherapy [63].

It can be observed for the whole analysed group of 12 miRNAs that their overexpression is associated with increased expression of mRNA transcripts, regulated by the miRNA (except for identified decrease in the transcriptional activity of DIAPH1 with the increased expression of regulating miRNAs: hsa-miR-1275, hsa-miR-143, hsa-miR-1909, and hsa-miR-199a-5p).

The analysis of cells treated for 8 hours with adalimumab shows an increase in the expression of miR-1909 and also EDN1, which is regulated by this miRNA.

The microarray analysis shows that there are only three differentiating miRNAs in cells treated for 24 hours with adalimumab. However, none of them is connected with any genes associated with histamine. It may suggest that the level of miRNA decreases with the exposure time.

miRNA-mediated regulation of gene expression in the anti-TNF therapy has been confirmed by Pivarsci et al. In his studies, he showed that anti-TNF therapy (etanercept) affects the change in the concentration of 38 miRNAs in the serum of patients with psoriasis treated with biological drugs [64]. In turn, Raaby et al. observed changes in the miRNA profile, during an adalimumab treatment in psoriatic skin biopsies.

The origin of miRNA in the RNA extract used in this study is unknown. An isolation of total RNA is associated with the presence of all types of RNA molecules in the extract. Therefore, it is possible that some of miRNA molecules in the generated extract originated from exosomes. Exosomes are membrane vesicles most likely secreted by cells of all types, involved in the intercellular communication. They contain a number of proteins, as well as the specific mRNAs and biologically active miRNAs regulating transcriptional activity of specific genes in target cells [65]. The exosomes may be responsible for the loss of efficacy of the analysed therapy. They are also used in the detection and evaluation of the severity of the condition [66].

The obtained results involving miRNAs indicate that the molecules play a certain role in the regulation of the expression of genes associated with the histaminergic system.

They also indicate that the expression profile of a particular gene can be controlled by several different miRNAs and it was observed that a single miRNA molecule acts as a regulator of more than one mRNA transcript.

In summary, based on the results of the described experiment, the anti-inflammatory effect of adalimumab has been confirmed, attributed to its ability to modulate expression of genes associated with the histaminergic system. The data also indicate the possibility to use the genes associated with the system and miRNAs regulating their expression as complementary therapeutic markers in personalized therapy. In addition, the sensitivity of cells to anti-TNF drug observed after two hours of skin fibroblasts incubation with the drug highlights the possibility to implement these molecular markers in routine diagnostics.

\section{Conflicts of Interest}

The authors declare that there are no conflicts of interest.

\section{Authors' Contributions}

All authors were responsible for the concept and design of the study, collection and collation of data, analysis and interpretation of data, writing of the article, reviewing of this article, final reviewing of this article, and graphics performance.

\section{Acknowledgments}

This research was financed by Medical University of Silesia in Katowice/Poland on the basis of decision no. KNW-1029/N/6/O. This research was supported in part by PLGrid Infrastructure.

\section{References}

[1] I. V. Litvinov, A. A. Bizet, Y. Binamer, D. A. Jones, D. Sasseville, and A. Philip, "CD109 release from the cell surface in human keratinocytes regulates TGF- $\beta$ receptor expression, TGF- $\beta$ signalling and STAT3 activation: relevance to psoriasis," Experimental Dermatology, vol. 20, no. 8, pp. 627-632, 2011.

[2] H. Wang, T. Peters, and A. Sindrilaru, “TGF-beta-dependent suppressive function of Tregs requires wild-type levels of CD18 in a mouse model of psoriasis," Journal of Clinical Investigation, vol. 118, no. 7, pp. 2629-2639, 2008.

[3] J. Szepietowski, Z. Adamski, G. Chodorowska et al., "Leczenie łuszczycy - rekomendacje ekspertów Polskiego Towarzystwa Dermatologicznego. Część II: łuszczyca umiarkowana do ciężkiej”, Przegląd Dermatologiczny, vol. 101, pp. 455-472, 2014.

[4] A. W. Armstrong, C. T. Harskamp, and E. J. Armstrong, "Psoriasis and metabolic syndrome: a systematic review and meta-analysis of observational studies," Journal of the American Academy of Dermatology, vol. 68, no. 4, pp. 654-662, 2013.

[5] U. Khalid, P. R. Hansen, G. H. Gislason et al., "Psoriasis and new-onset diabetes: a Danish nationwide cohort study," Diabetes Care, vol. 36, no. 8, pp. 2402-2407, 2013.

[6] J. Machado-Pinto, M. d. Diniz, and N. C. Bavoso, "Psoriasis: new comorbidities," Anais Brasileiros de Dermatologia, vol. 91, no. 1, pp. 8-16, 2016.

[7] A. Michalak-Stoma, A. Pietrzak, J. C. Szepietowski, A. Zalewska-Janowska, T. Paszkowski, and G. Chodorowska, "Cytokine network in psoriasis revisited," European Cytokine Network, vol. 22, no. 4, pp. 160-168, 2011.

[8] M. A. Lowes, M. Suárez-Fariñas, and J. G. Krueger, "Immunology of psoriasis," Annual Review of Immunology, vol. 32, pp. 227-255, 2014.

[9] W. R. Swindell, A. Johnston, J. J. Voorhees, J. T. Elder, and J. E. Gudjonsson, "Dissecting the psoriasis transcriptome: inflammatory- and cytokine-driven gene expression in lesions from 163 patients," BMC Genomics, vol. 14, no. 1, article 527, 2013.

[10] M. Kunz and S. M. Ibrahim, "Cytokines and cytokine profiles in human autoimmune diseases and animal models of autoimmunity," Mediators of Inflammation, vol. 2009, Article ID 979258, 20 pages, 2009.

[11] Całkosiński, I. Bradley, and M. Dobrzynski, "Charakterystyka procesu zapalnego," Postepy Higieny Medycyny Doswiadczalnej, vol. 63 , pp. 395-408, 2009.

[12] J. R. Bradley, “TNF-mediated inflammatory disease," The Journal of Pathology, vol. 214, no. 2, pp. 149-160, 2008. 
[13] R. Tian, G. Hou, D. Li, and T. Yuan, "A possible change process of inflammatory cytokines in the prolonged chronic stress and its ultimate implications for health," The Scientific World Journal, vol. 2014, Article ID 780616, 8 pages, 2014.

[14] C. E. Joyce, X. Zhou, J. Xia et al., "Deep sequencing of small RNAs from human skin reveals major alterations in the psoriasis miRNAome," Human Molecular Genetics, vol. 20, no. 20, pp. 4025-4040, 2011.

[15] E. Sonkoly, T. Wei, and P. C. J. Janson, "MicroRNAs: novel regulators involved in the pathogenesis of psoriasis?" PLOS ONE, vol. 2, no. 7, Article ID e0000610, 8 pages, 2007.

[16] J. E. Hawkes, G. H. Nguyen, M. Fujita et al., "microRNAs in Psoriasis," Journal of Investigative Dermatology, vol. 136, no. 2, pp. 365-371, 2016.

[17] R.-Y. Huang, L. Li, M.-J. Wang, X.-M. Chen, Q.-C. Huang, and C.-J. Lu, "An exploration of the role of MicroRNAs in psoriasis: a systematic review of the literature," Medicine, vol. 94, no. 45, Article ID e2030, 2015.

[18] N. S. Seifeldin, S. B. El Sayed, and M. K. Asaad, "Increased MicroRNA-1266 levels as a biomarker for disease activity in psoriasis vulgaris," International Journal of Dermatology, vol. 55, no. 11, pp. 1242-1247, 2016.

[19] S. García-Rodríguez, S. Arias-Santiago, G. Blasco-Morente et al., "Increased expression of microRNA-155 in peripheral blood mononuclear cells from psoriasis patients is related to disease activity," Journal of the European Academy of Dermatology and Venereology, vol. 31, no. 2, pp. 312-322, 2017.

[20] G. Lerman, C. Avivi, C. Mardoukh et al., "MiRNA expression in psoriatic skin: Reciprocal regulation of hsa-miR-99a and IGF1R," PLoS ONE, vol. 6, no. 6, Article ID e20916, 13 pages, 2011.

[21] M. Shahid, T. Tripathi, F. Sobia, S. Moin, M. Siddiqui, and R. A. Khan, "Histamine, histamine receptors, and their role in immunomodulation: an updated systematic review," Open Immunology Journal, vol. 2, no. 1, pp. 9-41, 2009.

[22] H. Stark, "Histamine receptors," Biotrend Reviews, vol. 11, pp. 19, 2007.

[23] P. Panula, M. Sundvik, and K. Karlstedt, "Developmental roles of brain histamine," Trends in Neurosciences, vol. 37, no. 3, pp. 159-168, 2014.

[24] J. Szepietowski, Z. Adamski, and G. Chodorowska, "Rekomendacje Polskiego Towarzystwa Dermatologicznego dotyczące stosowania leków biologicznych w łuszczycy zwyczajnej i stawowej (łuszczycowym zapaleniu stawów)," Przegląd Dermatologiczny, vol. 97, pp. 1-13, 2010.

[25] S. Garces, J. Demengeot, and E. Benito-Garcia, "The immunogenicity of anti-TNF therapy in immune-mediated inflammatory diseases: a systematic review of the literature with a metaanalysis," Annals of the Rheumatic Diseases, vol. 72, no. 12, pp. 1947-1955, 2013.

[26] M. E. Weinblatt, E. C. Keystone, D. E. Furst et al., "Adalimumab, a fully human anti-tumor necrosis factor $\alpha$ monoclonal antibody, for the treatment of rheumatoid arthritis in patients taking concomitant methotrexate: the ARMADA trial," Arthritis \& Rheumatism, vol. 48, no. 1, pp. 35-45, 2003.

[27] L. B. A. Van De Putte, C. Atkins, M. Malaise et al., "Efficacy and safety of adalimumab as monotherapy in patients with rheumatoid arthritis for whom previous disease modifying antirheumatic drug treatment has failed," Annals of the Rheumatic Diseases, vol. 63, no. 5, pp. 508-516, 2004.

[28] C. Monaco, J. Nanchahal, P. Taylor, and M. Feldmann, "AntiTNF therapy: past, present and future," International Immunology, vol. 27, no. 1, pp. 55-62, 2014.
[29] R. Nishikawa, H. Nagai, T. Bito et al., "Genetic prediction of the effectiveness of biologics for psoriasis treatment," The Journal of Dermatology, vol. 43, no. 11, pp. 1273-1277, 2016.

[30] G. Murdaca, F. Spanò, M. Contatore, A. Guastalla, O. Magnani, and F. Puppo, "Pharmacogenetics of etanercept: Role of TNF- $\alpha$ gene polymorphisms in improving its efficacy," Expert Opinion on Drug Metabolism \& Toxicology, vol. 10, no. 12, pp. 1703-1710, 2014.

[31] A. Wegner, M. Szychta, and J. Kierkuś, "Rola terapii biologicznej $\mathrm{w}$ podtrzymaniu remisji u dzieci z chorobą Leśniowskiego i Crohna," Pediatria Polska, vol. 88, no. 2, pp. 131-137, 2013.

[32] D. Domżał-Magrowska, R. Talar-Wojnarowska, J. Kotynia, Ł. Durko, and E. Małecka- Panas, "Skuteczność i bezpieczeństwo terapii biologicznej w przebiegu chorobie Leśniowskiego Crohna - doświadczenia własne," Prz Gastroenterol, vol. 6, no. 5, pp. 304-309, 2011.

[33] K. Michaelis, K. Wallbrecht, A. Kerstan et al., "Modulating T cell functions does not alleviate chronic inflammatory skin lesions in K5.TGF $\beta 1$ transgenic mice," Experimental Dermatology, vol. 19, no. 5, pp. 406-415, 2010.

[34] S. Hoffjan and S. Stemmler, "On the role of the epidermal differentiation complex in ichthyosis vulgaris, atopic dermatitis and psoriasis," British Journal of Dermatology, vol. 157, no. 3, pp. 441-449, 2007.

[35] E. Tschachler, "Psoriasis: the epidermal component," Clinics in Dermatology, vol. 25, no. 6, pp. 589-595, 2007.

[36] M. Gschwandtner, M. Mildner, V. Mlitz et al., "Histamine suppresses epidermal keratinocyte differentiation and impairs skin barrier function in a human skin model," Allergy: European Journal of Allergy and Clinical Immunology, vol. 68, no. 1, pp. 3747, 2013.

[37] T. Ruzicka and S. Glück, "Cutaneous histamine levels and histamine releasability from the skin in atopic dermatitis and hyperIgE-syndrome," Archives of Dermatological Research, vol. 275, no. 1, pp. 41-44, 1983.

[38] F. E. R. Simons and K. J. Simons, "The pharmacology and use of H1-receptor - antagonist drugs," The New England Journal of Medicine, vol. 330, no. 23, pp. 1663-1670, 1994.

[39] M. Honardoost, E. Arefan, M. Soleimani, S. Soudi, and M. R. Sarookhani, "Development of insulin resistance through induction of miRNA-135 in C2C12 cells," Cell, vol. 18, no. 3, pp. 353361, 2016.

[40] J. Pan, L. Lordier, D. Meyran et al., "The formin DIAPH1 (mDial) regulates megakaryocyte proplatelet formation by remodeling the actin and microtubule cytoskeletons," Blood, vol. 124, no. 26, pp. 3967-3977, 2014.

[41] Y.-N. Lin, J. R. Izbicki, A. König et al., "Expression of DIAPH1 is up-regulated in colorectal cancer and its down-regulation strongly reduces the metastatic capacity of colon carcinoma cells," International Journal of Cancer, vol. 134, no. 7, pp. 15711582, 2014.

[42] G. Bongers, I. de Esch, and R. Leurs, "Molecular pharmacology of the four histamine receptors," in Histamine in Inflammation, vol. 709 of Advances in Experimental Medicine and Biology, pp. 11-19, Springer US, Boston, Mass, USA, 2010.

[43] F. E. R. Simons and K. J. Simons, "Histamine and $\mathrm{H}_{1}$-antihistamines: celebrating a century of progress," The Journal of Allergy and Clinical Immunology, vol. 128, no. 6, pp. 1139-1150, 2011.

[44] M. Romanowska and M. Komoszyński, "Adenosine-neurotransmitter and neuromodulator in the central nervous system," Postepy Biochemii, vol. 48, no. 3, pp. 230-238, 2002. 
[45] B. Ghaderi, S. Amini, F. Maroofi et al., "Adenosine deaminase activity in chronic lymphocytic leukemia and healthy subjects," Iranian Journal of Cancer Prevention, vol. 9, no. 3, Article ID e5069, pp. 1-6, 2016.

[46] H. T. Lynch, O. Kosoko-Lasaki, S. W. Leslie et al., "Screening for familial and hereditary prostate cancer," International Journal of Cancer, vol. 138, no. 11, pp. 2579-2591, 2016.

[47] I. Cheng, S. J. Plummer, C. Neslund-Dudas et al., "Prostate cancer susceptibility variants confer increased risk of disease progression," Cancer Epidemiology, Biomarkers \& Prevention, vol. 19, no. 9, pp. 2124-2132, 2010.

[48] L. Li, M. He, L. Zhou et al., "A solute carrier family 22 member 3 variant rs3088442 G3A associated with coronary heart disease inhibits lipopolysaccharide-induced inflammatory response," The Journal of Biological Chemistry, vol. 290, no. 9, pp. 53285340, 2015.

[49] T. Kun and R. Dąbrowski, "Endoteliny w regulacji funkcji układu krążenia," Polski Przegląd Kardiologiczny, no. 4, pp. 149155, 2002.

[50] A. Bagnato, F. Spinella, and L. Rosanò, "Emerging role of the endothelin axis in ovarian tumor progression," EndocrineRelated Cancer, vol. 12, no. 4, pp. 761-772, 2005.

[51] L. Rosanò, V. Di Castro, F. Spinella et al., "Combined targeting of endothelin a receptor and epidermal growth factor receptor in ovarian cancer shows enhanced antitumor activity," Cancer Research, vol. 67, no. 13, pp. 6351-6359, 2007.

[52] J. Oleander, M. Stachowicz, and J. Szota, "Endotelina jako cel terapeutyczny w raku jelita grubego," in Fram Przegląd Naukowy, vol. 9-10, pp. 6-9, 2008.

[53] I. Sacewicz, M. Wiktorska, T. Wysocki, and J. Niewiarowska, "Mechanizmy angiogenezy nowotworowej," Postepy Higieny Medycyny Doswiadczalnej, vol. 63, pp. 159-168, 2009.

[54] C. Lock, G. Hermans, R. Pedotti et al., "Gene-microarray analysis of multiple sclerosis lesions yields new targets validated in autoimmune encephalomyelitis," Nature Medicine, vol. 8, no. 5, pp. 500-508, 2002.

[55] S. L. Romero-Cordoba, I. Salido-Guadarrama, M. RodriguezDorantes, and A. Hidalgo-Miranda, "miRNA biogenesis: biological impact in the development of cancer," Cancer Biology \& Therapy, vol. 15, no. 11, pp. 1444-1455, 2014.

[56] B. Hukowska-Szematowicz and B. Deptuła, "Biologiczna rola mikroRNA (miRNA) - nowe dane," in Postępy Biologii Komórki, vol. 37, pp. 1-13, 2010.

[57] A. Stachurska, P. Stachurski, and M. Malecki, "MikroRNA w chorobach układu sercowo-naczyniowego," Choroby Serca $i$ Naczyń, vol. 8, no. 3, pp. 158-164, 2011.

[58] J. Mytych, "a znaczące - rola mikroRNA w powstawaniu, detekcji oraz leczeniu nowotworów na przykładzie nowotworu żołądka," in Medical Review, vol. 3, pp. 366-372, 2012.

[59] A. Grenda, M. Budzyńsk, and A. Filip, "Biogeneza cząsteczek mikroRNA oraz ich znaczenie w powstawaniu i przebiegu wybranych zaburzeń hematologicznych," in Postepy Higieny Medycyny Doswiadczalnej, vol. 67, pp. 174-185, 2013.

[60] N. Kavitha, S. Vijayarathna, S. L. Jothy et al., "MicroRNAs: Biogenesis, roles for carcinogenesis and as potential biomarkers for cancer diagnosis and prognosis," Asian Pacific Journal of Cancer Prevention, vol. 15, no. 18, pp. 7489-7497, 2014.

[61] J. Zhang, S. Li, L. Li et al., "Exosome and exosomal microrna: trafficking, sorting, and function," Genomics, Proteomics \& Bioinformatics, vol. 13, no. 1, pp. 17-24, 2015.
[62] D. Betel, M. Wilson, A. Gabow, D. S. Marks, and C. Sander "The microRNA.org resource: targets and expression," Nucleic Acids Research, vol. 36, no. 1, pp. 149-153, 2008.

[63] S. B. Krintel, C. Dehlendorff, M. L. Hetland et al., "Prediction of treatment response to adalimumab: A double-blind placebocontrolled study of circulating microRNA in patients with early rheumatoid arthritis," The Pharmacogenomics Journal, vol. 16, no. 2, pp. 141-146, 2016.

[64] A. Pivarcsi, F. Meisgen, N. Xu, and E. Sonkoly, "Changes in the level of serum microRNAs in patients with psoriasis after antitumour necrosis factor- $\alpha$ therapy," British Journal of Dermatology, vol. 169, no. 3, pp. 563-570, 2013.

[65] E. Sikora, W. Ptak, and K. Bryniarski, "Immunoregulacja poprzez interferencyjny RNA - mechanizmy, rola, perspektywy," Postepy Higieny Medycyny Doswiadczalnej, vol. 65, pp. 482-495, 2011.

[66] A. Wójtowicz, M. Baj-Krzyworzeka, and J. Baran, "Charakterystyka i znaczenie biologiczne mikropęcherzyków błonowych," Postepy Higieny i Medycyny Doswiadczalnej, vol. 68, pp. 14211432, 2014. 


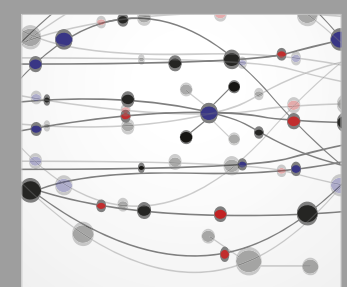

The Scientific World Journal
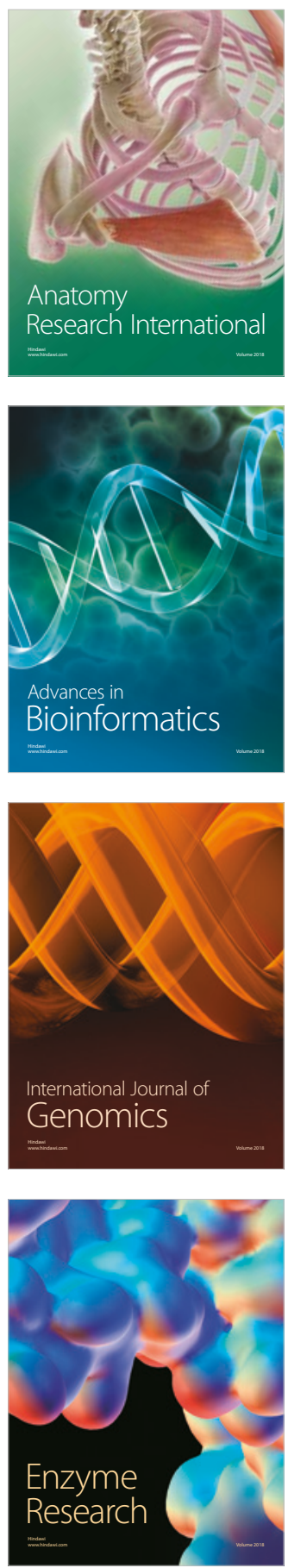
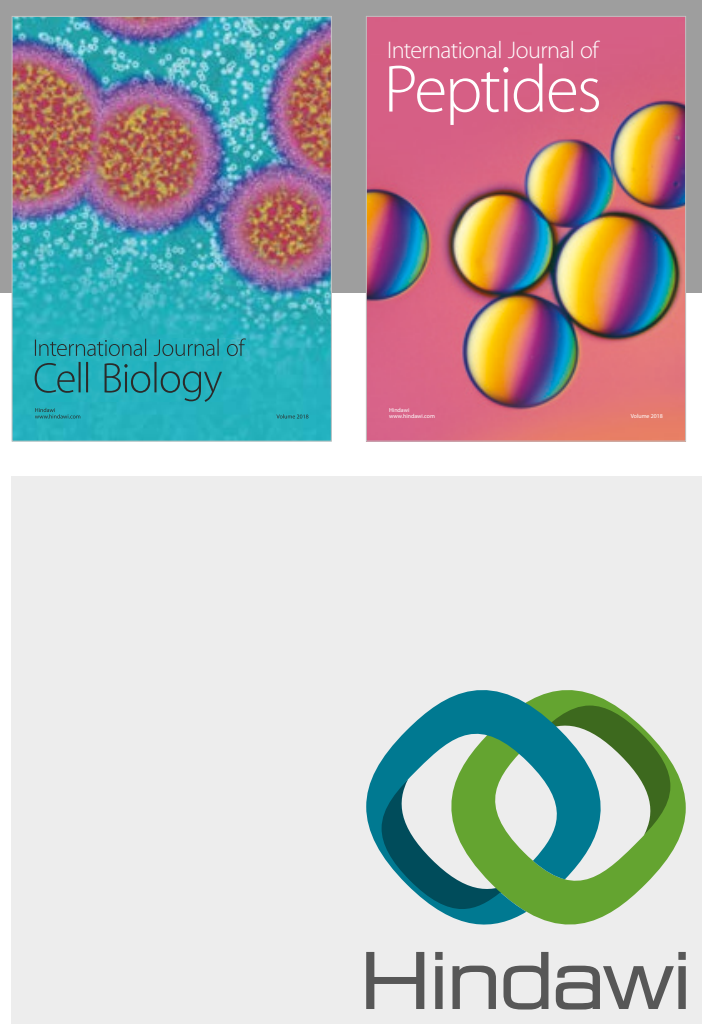

Submit your manuscripts at

www.hindawi.com
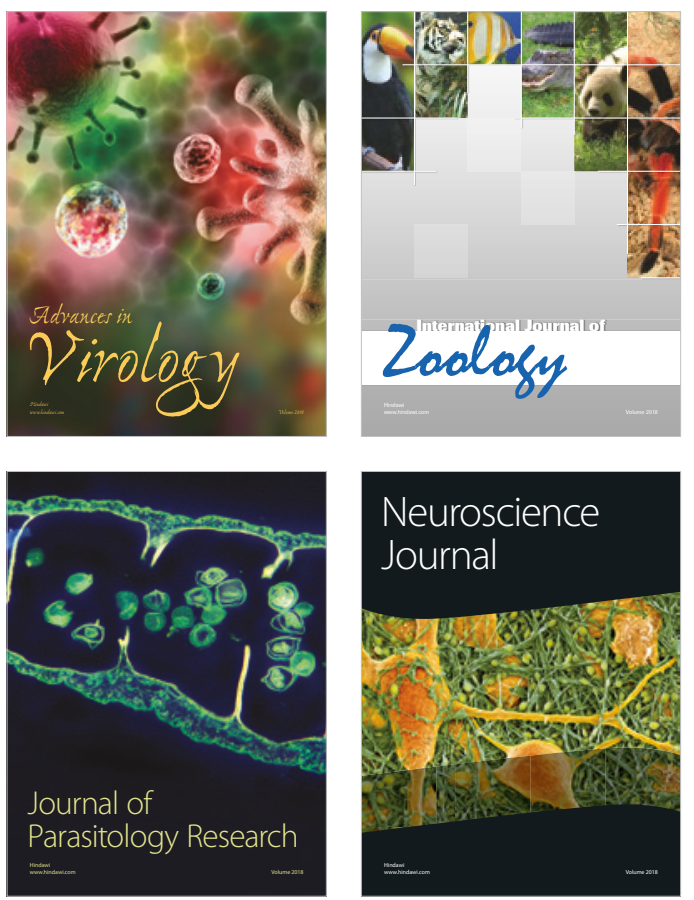
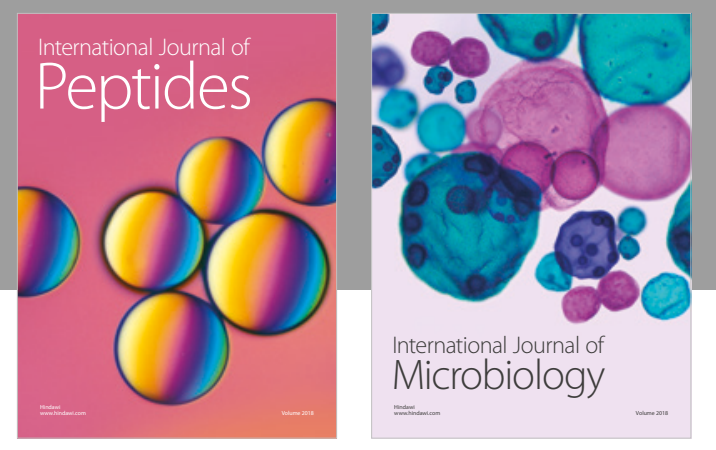

nternational Journal of Microbiology
Journal of
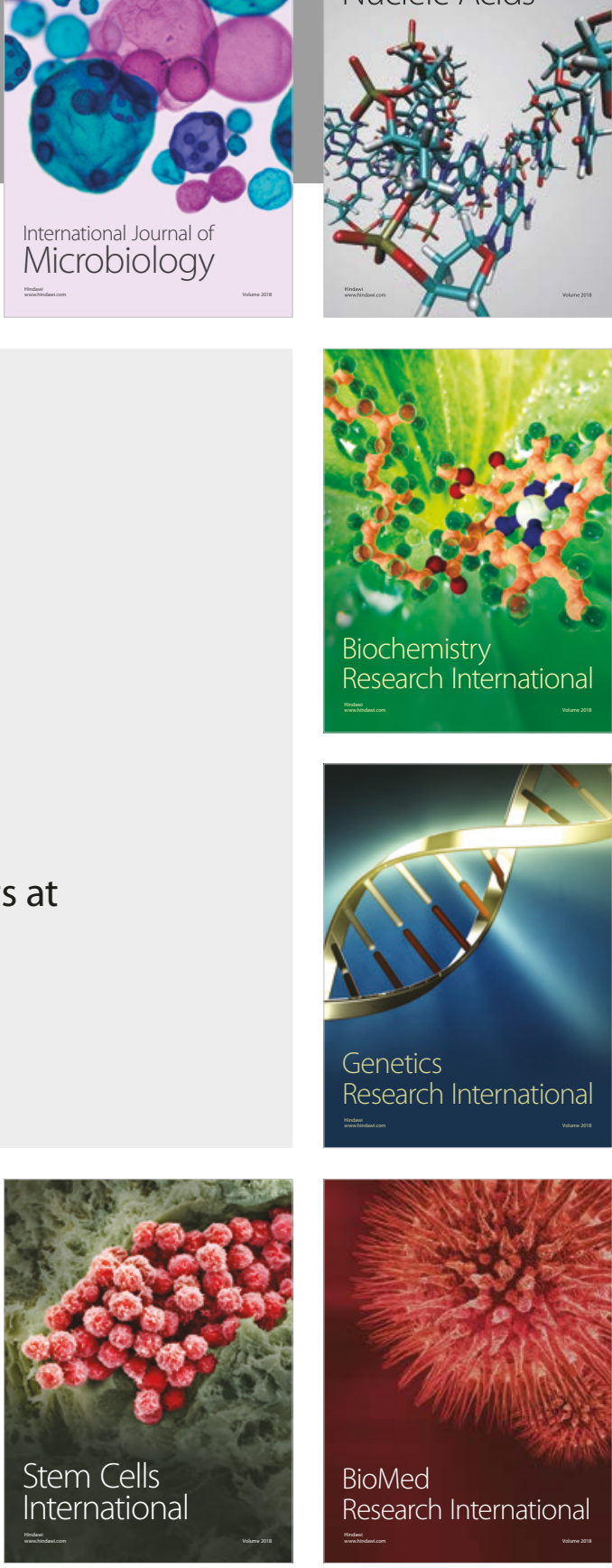
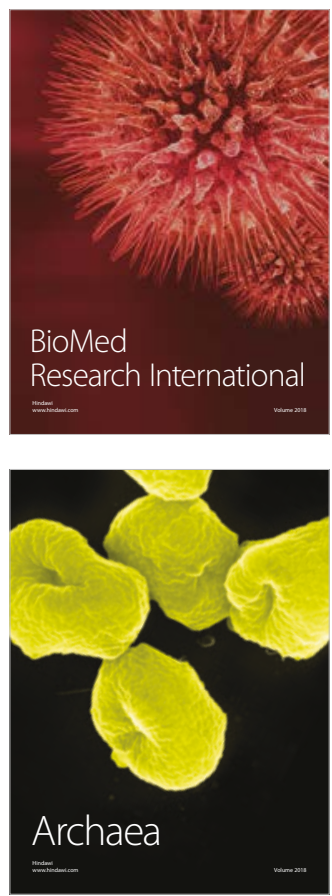